\title{
DETERMINANTS OF CAPITAL BUDGETING METHODS AND HURDLE RATES IN NORDIC FIRMS
}

\author{
Tor Brunzell, Eva Liljeblom and Mika Vaihekoski
}

January 14, 2011

Comments are welcome.

\begin{abstract}
Using survey data for 157 Nordic firms, we study the determinants for the choice of capital budgeting methods and the setting of hurdle rates (WACCs) in five Nordic countries. We combine survey data with a rich set of determinants, including ownership data, CFO characteristics, as well as financial data (firm characteristics). We find that the use of the NPV method as a primary method, and the sophistication of the capital budgeting, is related both to firm characteristics, variables proxying for real option features in investments, as well as to CFO characteristics (age and education). We also find support for a significant positive hurdle rate premium (i.e. a hurdle rate higher than motivated by economic theory). The premium is weakly related to managerial short-term pressure, and strongly negatively to the sophistication level of the firm's capital budgeting. This relationship goes in line with the predictions from real options and agency theory, since explanations from both categories combine the use of higher hurdle rates with a higher use of multiple methods and "rules of thumb".
\end{abstract}

KEYWORDS: capital budgeting methods, hurdle rate, WACC, NPV, IRR, Nordic countries

JEL Classification: G31, M21, O16

In alphabetical order. Brunzell: Stockholm University, School of Business. E-mail: tb(at)fek.su.se. Liljeblom: Hanken School of Economics, Department of Finance and Statistics. E-mail: eva.liljeblom(at)hanken.fi. Vaihekoski: Turku School of Economics, Department of Accounting and Finance and Lappeenranta University of Technology, School of Business. E-mail: mika.vaihekoski(at)tse.fi. Authors wish to thank Nils Liljendahl, Kirsi Noro, Magnus Blomkvist, and Anna Björn for research assistance. Financial support from NASDAQ OMX Nordic Foundation and Academy of Finland is gratefully acknowledged. 


\section{INTRODUCTION}

Since early surveys (see e.g. Klammer 1972, Brigham 1975) of capital budgeting methods used in firms, discounted cash flow (DCF) based methods such as the Internal Rate of Return (IRR) and, especially, the Net Present Value (NVP) rule, have increasingly gained ground as the main methods in evaluating investment decisions. ${ }^{1}$ Despite some debate concerning the appropriateness of the NPV in all situations ${ }^{2}$, the NPV is generally considered superior to e.g. the pay-back method and the IRR. ${ }^{3}$ However, several puzzling empirical findings concerning capital budgeting methods and the setting of discount rates for projects remain. These include the wide-spread use of "unsophisticated" investment evaluation methods, as well as the hurdle rate premium puzzle: the hurdle rates used seem typically too high as compared to rates suggested by financial theory.

We contribute to the literature on the choice of capital budgeting methods and the choice of the discount rate by studying the determinants of these in five Nordic countries. Combining survey responses with detailed firm level financials as well as ownership data, and data on respondent characteristics (such as age and education) we are able to use a set of explanatory variables which is more extensive than in the previous papers. Using the dataset, we test suggested predictions for the use of different capital budgeting methods, and determinants for the hurdle rate premium. We also produce an index for the "sophistication" level of the capital budgeting methods used. We find that the use of the NPV method as a primary method, and the sophistication of the firms capital budgeting, are linked both to firm characteristics (size), variables proxying for real option features in the firms investment projects, but also to CFO

1 In the Brigham (1975) study, 94\% of the large U.S. firms in their survey use NPV, IRR or a profitability index criterion in their capital budgeting. In most U.S. studies from 1977 (Gitman and Forrester 1977) to the early 2000's (Stanley and Block 1984, Bierman 1993, Graham and Harvey 2002), NPV and /or IRR are typically the most common method(s), with IRR being either more or at least approximately equally common as the NPV. For Europe, Brounen et al. (2004) report that pay-back is still the most common. See also e.g. Jagannathan and Meier (2002) and Anand (2002) for evidence and review of capital budgeting methods and their development over time. For the Nordic markets studied here, see Holmén and Pramborg (2006) for Sweden, and Liljeblom and Vaihekoski (2004) for Finland.

2 The appropriateness has been questioned e.g. due to agency problems within the firm, the way WACC is implemented, or disequilibrium related non-additivity, see Berkovitch and Israel (1998), Miller (2009), Pierru (2009), and Magni (2008).

3 Empirical studies also indicate an increasing use of methods complementing the DCF calculus e.g. by real options applications (see e.g. Graham and Harvey 2002). 
characteristics (age and education). We also study the setting of the hurdle rate, and in line with Meier and Tarhan (2007), find support for a significant positive hurdle rate premium. As determinants for the hurdle rate premium, we find weak support for managerial pressure for short-termism, and strong support for a relationship between the sophistication of the capital budgeting in the firm, and a high hurdle rate. This result goes in line predictions from two categories of theories, i.e. investments having real options characteristics, as well as agency cost / complex structures within the firm, since explanations from both categories combine the use of higher hurdle rates with a higher use of multiple methods and "rules of thumb".

Our study addresses several puzzling empirical findings concerning capital budgeting methods and the setting of discount rates for projects. First, a high number of firms still use unsophisticated capital investment evaluation methods. Different reasons for the lack of sophisticated investment evaluation methods as well as the common use of "rules of thumb" in capital budgeting has been suggested e.g. by Poterba and Summers (1995), Jagannathan and Meier (2002), Berkovitch and Israel (2004), McDonald (2000 and 2006), Holmén and Pramborg (2006), and Magni (2009). These include curbing with managerial over-optimism and agency problems related to project approval, limited managerial and organizational capital, implicitly including elements from real option valuation, taking into account political risk, as well as bounded rationality. Other papers relate the education of the CFO to the use of more sophisticated capital budgeting methods, as in Graham and Harvey (2002) and Meier and Tarhan (2007), or estimate binary models explaining choices of capital budgeting methods, as in Brounen et al. (2004) and Hermes et al. (2005). However, there is still a shortage of studies looking into cross-sectional determinants of the choices of capital budgeting methods in a broader context. ${ }^{4}$

\footnotetext{
While Hermes et al. (2005) study only country effects and CFO characteristics, Brounen at al. (2004) estimate multivariate probit models to study four aspects: the use of DCF methods, whether cost of capital is computed, the CAPM used, and whether more sophisticated discount rates for investment projects are applied. They use data for four European countries: the U.K., the Netherlands, Germany, and France (313 observations). However, both of these studies use a rather limited set of explanatory variables such as country dummies, firm size, shareholder orientation (in Brounen et al 2004), an industry dummy (in Hermes et al 2005), CEO education, CEO age (in Hermes et al 2005), and a dummy for whether the firm is listed (in Brounen at al 2004). We contribute by a richer set of explanatory variables based e.g. on firm and ownership characteristics, and by more directly testing different hypotheses concerning the determinants of the sophistication of capital budgeting methods. Our paper is also the first comprehensive study of capital budgeting in all the Nordic countries, and we study only listed firms, which gives a better comparison to many studies mixing listed or large ("Fortune 500") firms.
} 
Second, survey results indicate that firms often do not take project specific risk fully into account; they often use a single discount rate for all projects, and also less frequently adjust it over time. ${ }^{5}$ Also, when asked to report an average nominal (or real) discount rate used for projects, this number exhibits surprisingly small variation across countries and time, and lately, has often appeared to be substantially higher than justified by the corporate finance theory. ${ }^{6}$ However, only few papers have explicitly studied the determinants of reported hurdle rates in the U.S. (see e.g. Poterba and Summers 1995; and Meier and Tarhan 2007). Meier and Tarhan (2007) in particular analyze in more detail this "hurdle rate premium puzzle", and indeed find that reported rates appear to be way too high as compared to reasonable rates obtained using empirical inputs for debt and equity, the CAPM for the calculation of the return on equity, and taking firm leverage into account. ${ }^{7}$

We contribute to the prior literature by providing a comprehensive analysis of the drivers of the development of capital budgeting methods, as well as the setting of hurdle rates. We contrast variables from two main category of explanations: 1.) explanatory variables for why the methods used may be "optimal"8 given agency problems within the firm (expectedly larger

5 Klammer (1972) reports that only $39 \%$ of the firms were using some specific formal method to adjust for risk (21\% were adjusting the rate of return required). In Gitman and Forrester (1977), 29\% did not give explicit consideration to risk. The most popular technique was to adjust the rate of return (42.7\%). In Gitman and Mercurio (1982), 33.3\% did not differentiate between project risk, and when they did, adjusting cash flows was slightly more common than adjusting the discount rate. Poterba and Summers (1995) report opposite findings since most firms in their sample used more than one hurdle rate, and used a lower one for strategic projects. In Graham and Harvey (2001), the dominating answer (with response frequencies ranging between $51.3 \%$ and $88.9 \%$ ) to whether the firm adjusts either cash flows or the discount rate to a list of risk factors was "neither"; moreover, most firms $(58.8 \%)$ would always or almost always use a single companywide discount rate to evaluate a project in an overseas market. In Liljeblom and Vaihekoski (2004) for Finland, $45.5 \%$ used the same discount rate as for the whole company (WACC), 60\% answered that the discount rate is changed only approximately once a year, and $25 \%$ does not change it every year. In Meier and Tarhan (2007), 52.5\% of the firms in their sample report that they did not change their hurdle rates during the three years preceding the survey date.

6 Examples of average discount rates reported include: mostly (in 57\% of the cases) between $10 \%$ and $15 \%$ in Gitman and Forrester (1977); $14.3 \%$ in Gitman and Mercurio (1982); a real rate of $12.2 \%$ in Poterba and Summers (1995); a nominal discount rate of $12.2 \%$ in Sandahl and Sjögren (2003) for Sweden; a mostly nominal discount rate of $15.2 \%$ in Liljeblom and Vaihekoski (2004); and a real hurdle rate of $11.6 \%$ in Meier and Tarhan (2007).

7 The puzzling observation of surprisingly high reported discount rates during more recent periods of low inflation has also earlier been discussed e.g. in Poterba and Summers (1995), and Liljeblom and Vaihekoski (2004).

8 Or, if not quite the optimal one, to some extent motivated. McDonald (2000) says, when discussing the potential approximate correctness of such rules of thumb, that "We do not suggest that managers should use these rules of thumb" (p. 30). 
in larger, often more complex or diversified firms, and in firms not closely controlled by the main owner), and option-like features in the firm's projects, and 2.) explanatory variables which relate to either external pressure (short-term pressure from shareholders or stakeholders) or internal behavioral characteristics (CFO age and education). This is a rich set of characteristics, not combined before in this way to study the determinants of capital budgeting methods.

The remainder of this paper proceeds as follows. The potential factors influencing the choice of capital budgeting methods and the hurdle rate are presented and discussed in the second section. The survey method and our background data are presented in section 3 , while we describe our dependent and explanatory variables in section 4 . In section 5 , we present the responses from the surveys, while the actual testing of the determinants of capital budgeting methods and the hurdle rate takes place in section 6 . The final section offers conclusions and some suggestions for further research.

\section{FACTORS INFLUENCING CAPITAL BUDGETING}

Meier and Tarhan (2007) summarize the typical primary findings from prior surveys as the following three: (1) over time, firms show an increasing tendency to use DCF-based methods, (2) firms mostly use WACC as the discount rate, and (3) when computing the discount rate, the cost of equity is typically inferred from the CAPM. They also compare prior surveys in their Figure 1, and find an increasing usage of these methods and models over time. These findings suggest an increasing sophistication in capital budgeting over time.

However, such a development may not be quite straightforward. Using "rules of thumb", multiple methods instead of primarily the NPV, and using hurdle rates that appear too high may be an approximately suitable due to other reasons. Next, we provide a brief survey of such "near-rational" suggested reasons for either the use of less "sophisticated" methods, or hurdle rates higher than the cost of capital. 
Real options. Jagannathan and Meier (2002) show that a hurdle premium (a hurdle rate higher than the cost of capital) may capture the option value, and that, given the uncertainty associated with the cost-of-capital, managers may choose a single, high enough hurdle rate that is near optimal for a range of costs of capital. ${ }^{9}$ They predict that a higher hurdle premium would be more likely for projects that require the use of skilled manpower, or special purpose facilities that take time to build and face organizational constraints, and lock in much of the capacity of the firm. For such projects, the option to wait would be more valuable, and hence the hurdle rate used might be higher independent of the project's systematic risk. I.e. firms with complex projects would have a higher hurdle rate premium.

McDonald (2006) suggests that the simultaneous use of many capital budgeting methods parallel to DCF, such as IRR, payback, and P/E multiples, may mean that managers perform a variety of formal calculations, and then make decisions by weighing the results and also using subjective judgment. A part of such judgment may represent their "adjustments" of DCF methods to take real option values into account.

Agency problems. Poterba and Summers (1995) suggest that some managers may set hurdle rates above their required returns as a way to correct for overly optimistic cash flow projections in projects they are asked to consider. For project managers (the ones who suggest the projects for top managers) to want to push their projects in such a way, there must be some rewards from getting their projects approved. Also relying on an agency explanation, Berkovitch and Israel (2004) suggest that in large corporations with a relatively high likelihood of realizing good investment opportunities, a centralized capital allocation process with hurdle rates above the cost of capital will be used. Smaller, manager owned companies will only consider the NPV rule, and the owner's personal preferences.

Martin (2008) suggests that also the use of a single discount rate instead of project specific rates may have its roots in managerial incentives to get projects, which benefit them personally, approved. Such incentives could encourage managers to inflate the expected cash-flows, and, if

\footnotetext{
9 They also show that a wide range of hurdle rates can result in decisions which are near optimal.
} 
possible, understate project risks. While systematic inflation of cash-flows is relatively easy to detect ex-post, it is harder to determine whether the discount rate used has been appropriate. To curb with the problem, firm may restrict the use of discount rates to a single one. Martin (2008) suggests that larger and more bureaucratic firms with multiple levels of management might be more subject to such incentive problems as compared to smaller firms run by their owners.

Political risk. Holmén and Pramborg (2006) focus on capital market imperfections, and suggest that since political risk may be non-linear, and involve a high degree of qualitative judgment, firm may tend to use of rules of thumb such a the payback method. They report that in their sample of Swedish firms, the use of NPV decreases with the political risk of the host country, and the use of the payback method increases.

CEO / CFO characteristics. Manager qualifications such as the level of their knowledge of capital budgeting methods may also matter. Graham and Harvey (2002) find that CEOs with MBAs are more likely than non-MBA CEOs to use NPV. Also Brounen et al. (2004) and Hermes et al. (2005) find that CFO's education (as well as age, in Hermes et al. 2005) are significant determinants for whether the firm uses NPV. ${ }^{10}$

Short-term pressure. Recently several studies (e.g. Graham et al. 2006), have reported evidence of value-destroying actions / myopic management decisions. If the managers feel pressure to produce improved results above all in the short-term, even actions that hurt longterm performance may be undertaken. Liljeblom and Vaihekoski (2009) studied effects of such short-term pressure. Using ownership data on the main owners, they grouped firms in potentially more long-term vs. short-term oriented firms, and found that reported WACCs (based on survey data) were significantly higher (17.1\% vs. $12.8 \%)$ among firms grouped as potentially more short-term oriented.

10 Hermes et al. (2005) found this result for firms in China, but not in the Netherlands, where the NPV is anyway much more common, and there is therefore less cross-sectional variation in its use. 
We will use explanatory variables related to the categories above as explanations for the choice of capital budgeting methods as well as hurdle rates. These variables will be discussed in the data section (section 3). While the first three groups suggest that cross-sectional differences between firms can exist even if they in general use rather "sophisticated" methods, since it may be "near-optimal" to use an alternative method to capture real option value, political risk, or to cope with agency problems, the last two categories suggest that behavioral aspects such as the manager's level of education, or other external factors (short-term pressure) influence and potentially distort capital budgeting in a harmful way.

\section{THE SURVEY AND BACKGROUND DATA}

\subsection{The survey}

This paper is based on the results of a questionnaire directed to all CFOs of firms listed and with a corporate headquarter in any one of the Nordic countries (Denmark, Finland, Iceland, Norway, and Sweden). ${ }^{11}$ The questionnaires included questions especially regarding the investment evaluation and capital budgeting decisions used in the firm as well as some common questions. Appendix 1 of this paper lists the questions used in the survey. ${ }^{12}$

The survey was conducted in two stages. In the first stage, the questionnaire was sent to the respondents in the Nordic firms listed on the exchanges operated by the OMX (now NASDAQ OMX), i.e. in Denmark, Finland, Iceland, and Sweden. This took place in early December 2007. In the second stage, in May 2008, the questionnaire was sent to the respondents in the firms listed at the Oslo Børs in Norway. The questionnaire was sent as a letter directed to a named respondent. The names and addresses of the respondents were hand-collected. Ultimately, the CFO questionnaire was planned to be sent to 780 firms, but in the case of 69 firms, we were unable to find a specific CFO, so the total number of surveys sent was 711 .

11 This study is part of a bigger research project. Questionnaires with partly overlapping questions were also sent to the Chairmen of the Board and CEOs. More details on the survey can be found in Brunzell et al. (2010).

12 The numbering of the questions is different from that in the survey, since the survey included more questions, such as questions concerning capital structure and dividend policy. 
The respondents were promised total anonymity i.e. the responses and the respondent's identity is only available to the researchers and the results are reported only as a group. We received 157 responses from the CFOs giving us an overall response rate was $22.1 \%$ Out of the 157 responses, we received most of the responses from Sweden (71) and least from Iceland (6). Figure 1 shows the distribution of the responses across different countries. The highest response rate was for the Icelandic companies (33.3\%), then Swedish (28.3\%), Danish (25.0\%), Finnish (18.8\%), and the lowest for Norwegian companies (12.9\%).

\subsection{Background data}

The responses were matched with background information on firm financials and ownership concentration. The financial data is collected primary from the Amadeus database. Missing items have been collected from Datastream and from annual reports downloaded from the companies' web-sites. The financials are from the last reporting year completed prior to the questionnaire was sent out, i.e. they are mainly from the year-end 2006 for Denmark, Finland, Iceland, and Sweden, and from 2007 for Norway. Year-end exchange rates have been used to convert all financials to Euros.

Financial data was collected for all of the companies. Table 1 reports descriptive statistics for the respondents (sample) and for the listed Nordic firms, meeting our listing criteria, at the time of the surveys. ${ }^{13}$ Statistics have been separated for financial and non-financial firms. The value of solidity is not reported for the financials due to cross-sectional differences in how it is reported (that group of firms is very heterogeneous, including e.g. listed funds or investment companies, as well as insurance companies). The results show that our firms are slightly larger than the population of firms in terms of the turnover, number of employees and total assets, especially when it comes to the financial firms. This is likely to be due to the fact that the appearance of a named CFO is likely to be correlated with the size of the company. Our nonfinancial firms are also marginally less profitable (lower ROA), whereas our sample of

${ }^{13}$ We did not include foreign ADRs nor "off-shore" firms i.e. firms with a non-Nordic headquarter. I.e. all the questionnaires were sent to a postal address in one of the five Nordic countries, with a return envelope prepaid for postage within the Nordic countries. Especially on the Norwegian market, several firms with a nonNordic headquarter were listed. These were typically firms in the oil or shipping industries. 
financials are more profitable. However, even though there are some differences, we conclude that our sample represents the total population quite well.

\section{VARIABLES}

\subsection{Our dependent variables}

To study the determinants of capital budgeting methods and the hurdle rate, we estimate two types of models. In both of these, we use explanatory variables which proxy for the potentially influencing factors as discussed earlier.

When studying the determinants of the capital budgeting method, we will, in line with Hermes et al. (2005), regress the responses to the different main method on potential determinants. Since NPV was used as the most common primary method (used by 64 as one of the primary methods, out of 155 respondents), and since there is a large dispersion between the other methods, we focus on the question of whether NPV was chosen as one of the primary methods. This will be measured by a binary variable NPV_as_primary, taking the value of one if the firm has responded that they use NPV as one of their primary methods.

We also construct four measures for the degree of "sophistication" of the capital budgeting method, and study determinants of such measures. Index_1 is the sum of three binary variables, each taking the value of one if the firm's response has indicate that they use the method in question / use the method in question as a primary method. These methods are: a discounted cash flow method, a discounted cash flow method as a primary method, and NPV as a primary method. Index_1 thus ranges from zero to three. Index_2 is the sum of Index_1 and a binary variable taking the value of 1 is the firm has indicated that they change their WACC over time. Index_3 is the sum of Index_2 and a binary variable, taking the value of one if the firm uses different WACCs for different projects. Finally, Index_4 is the sum of Index_3 and a binary variable, taking the value of one if the firm uses different WACCs for projects otherwise identical but with a different project length. Index_4 thus ranges between zero and six.

The dependent variable in the hurdle rate model is a hurdle rate premium, calculated as the difference between a WACC obtained (WACC_survey) as a survey response, and a theoretical WACC calculated by us (WACC_theor). The survey variable was collected through the same 
survey as the responses to the capital evaluation methods, and was the answer to a question concerning "the required rate of return for the whole company (WACC)". Out of 144 responses, we obtained 82 values for such a WACC, a number closely corresponding to that in Meier and Tarhan (2007). ${ }^{14}$ The theoretical WACC was calculated using inputs for the return on equity and before-tax debt, and corporate (flat) tax rates from the time of the survey for the five Nordic countries (see Liljeblom 2008 for a survey of taxation in the Nordic countries). The returns on equity were calculated using the CAPM, with firm specific estimated betas based on prior one-year stock returns and local market indexes, using ten-year local currency government bond yields as the risk-free rate, and an expected equity risk premium of $5 \%$ for each country. ${ }^{15}$ As the return on debt, we use the ten-year local currency government bond yields plus a hypothetical margin of one percent. The fact that we do not adjust the rate of return requirement of debt for firm specific differences in default risk is unfortunate, but we do not have access to better data, i.e. data on firm specific costs of debt. ${ }^{16}$ At the time of the survey (prior to the financial crisis), however, corporate bond margins were rather narrow in the Nordic countries. Finally, we use market values of equity and book values of debt (Datastream, financial statement data) to calculate weights for equity and debt for the WACC formula. ${ }^{17}$ I.e., in line with Meier and Tarhan (2007), we assume that the current capital structure also is the target capital structure.

\subsection{The explanatory variables}

For most of the factors discussed in section two, i.e. factors which may influence capital budgeting and hurdle rates, we create some empirical proxy variables. We will describe them under the relevant categories.

\footnotetext{
14 Their number of observations range from 85 to 70 when analyzing the WACC and the hurdle premium.

$155 \%$ is a compromise in many ways. First, it is a common assumption for a long-run (arithmetic) equity premium, see e.g. Welch (2001) who reports values of 5\% or 5.5\%. Second, it is close to the arithmetic average of the equity premiums reported by finance professors from four Nordic countries in the international survey by Fernandez and del Campo (2010). That survey (of 1.500 academics) reports country averages, which are 3.6\% for Denmark, 5\% for Finland, and 5.3\% both for Sweden and Norway. See also e.g. Meier and Tarhan (2007), who in their hurdle rate estimation use two alternatives for the equity premium, $6.6 \%$ and $3.6 \%$.

16 Bank debt is still a common form of financing in the Nordic countries, so only a fraction of the firms in our sample might have issued traded bonds, for which yield data might be obtainable.

${ }^{17}$ Lack of input data for the calculation of equity weights lead to the loss of one observation for the theoretical WACC.
} 
Real options. To proxy for the existence of real options, we use Past_Growth (change in sales between two past years). ${ }^{18}$ To capture potential momentum in growth options, we also include ROA, defined as net profit to total assets. As suggested by Jagannathan and Meier (2002), we expect that firms with more real options will use a higher hurdle rate. As McDonald (2006) suggests, we expect that firms with more real options will use a larger variety of methods including more "rule of thumb" methods. Although they also may use NPV with real options as one method, the use of many methods may make them less likely to report the NPV method as their main one. We therefore expect negative signs for Past_Growth and ROA in the model for NPV as the main method, and positive ones in the hurdle rate model.

Agency problems. Martin (2008) suggests that larger and more bureaucratic firms with multiple levels of management might be more subject to incentive problems influencing capital budgeting. We therefore include Size, measured as the natural logarithm of sales. A problem with size is that larger firms are typically found (see e.g. Payne et al 1999, and Brounen et al 2004) to use (and may be required to use) more sophisticated methods, i.e. size captures other influences besides being a measure of complexity. We therefore also include SIC, a measure for firm level diversification (potentially related to complexity and / or multiple levels of management), calculated as the number of different sic-codes for the firm at the $2^{\text {nd }}$ digit level. We also use a combined variable, Large_and_Div, which is a combination of a dummy variable taking the value of 1 for firms with sales in excess of one billion euros, and the above SIC variable. This interaction variable is included in order to test for size related nonlinearities in the effect of SIC on capital budgeting. We expect a negative sign for SIC as our main variable for firm complexity in the capital budgeting equation, and a positive one in the hurdle rate model.

Both Berkovitch and Israel (2004) as well as Martin (2008) suggest that owner-run / ownercontrolled companies will be less subject to such agency problems which influence capital budgeting methods. In line with Berkovitch and Israel (2004), we expect that higher hurdle

\footnotetext{
${ }^{18}$ In line with Meier and Tarhan (2007), we also alternatively use the Market_to_Book value for the firm (market value of equity over book value of equity), from the last reporting year prior to the survey, as all the financials. The source of this variable is Datastream, complemented with hand-collected data for the components in the variable. Our results (not reported here) are robust to this specification as far as the other variables are concerned, but Market_to_Book in itself has a lower explanatory power as compared to Past_Growth.
} 
rates will be used by large, more diversified firms with more dispersed ownership. In line with both Berkovitch and Israel (2004) and Martin (2008), we expect that smaller, ownercontrolled firms will more likely use NPV as the single main method, whereas large, diversified firms with a higher degree of ownership dispersion will more often use multiple methods including "rules of thumb". We include the variable Large_owner, defined as the largest owners share of equity, to test for differences between firms with a high versus low level of ownership control.

Political risk. Holmén and Pramborg (2006) find that the use of NPV decreases with the political risk of the host country, whereas the use of the payback method increases at the same time. We study firms in the Nordic countries, which are not likely to differ much in terms of political risks. We will include country dummies for Denmark, Finland, and Sweden, leaving Norway and the few Icelandic firms to be represented by the intercept. These may, among other factors, capture potential differences in country risk premiums (in the hurdle rate models) as well as differences in political risks.

CFO characteristics. To proxy for the level of the CFO's education, we include a dummy CFO_edu, which takes the value of one if he has an MBA or a university degree in economics / management. We also include the variable CFO_age, which measures the age of the CFO in full years. Alternatively to CFO_age, we use the variable CFO_age_above_50, a dummy variable taking the value of one if the CFO is older than 50, and zero otherwise. In line with the results of both Graham and Harvey (2002) as well as Hermes et al. (2005) for Chinese managers, we expect that the use of more "sophisticated" methods, especially the NPV, is more common when the CFO has an economic education and is younger. We also include these into the hurdle rate equation, to test for potential effects concerning the "hurdle rate puzzle", i.e. we expect a smaller hudle rate premium in firms with a younger $\mathrm{CFO}$ and a CFO with an education in economics / business.

Short-term pressure. The results of Liljeblom and Vaihekoski (2009), who find significant differences between reported WACCs for firm owned by potentially more short-term vs. longterm owners, indicate that perceived pressure for short-term actions might influence the setting of the hurdle rate. We include the variable CFO_pressure, which is based on the CFO's reply on the question 'to what extend do you feel that short-term external expectations conflict with 
company's long-term goals?' with given alternatives 1 (very little) to 5 (very much). The mean answer to the question was 2.73. We expect that firms subject to more short-term pressure will be more focused on near-term results and therefore will rely more on the pay-back method i.e. a method other than the NPV, and use a higher hurdle rate. Appendix 2 describes our main variables and Appendix 3 reports some summary statistics for them.

Finally, we include industry dummies for two sectors: financials (FIN_SEC) and industrials (IND_SEC). These are the two largest sectors in our sample, and 72 firms (i.e. $46 \%$ of our sample) belong to these sectors.

\section{SURVEY RESPONSES}

\subsection{The investment evaluation method}

We asked the companies to indicate what kind of investment evaluation methods they use. A list of different methods was given with an option to provide their own (see Appendix 1). Respondents were asked to select only one primary method, but they could also select a number of secondary methods as well as indicate methods that are use only in some special cases.

Table 2 summaries the overall results. We received responses from 155 firms (CFOs) to this question. Contrary to the instructions, the firms selected in some cases several methods as their primary investment evaluation method giving us a total of 219 replies. The most popular method was, as expected, the NPV. Among the responding firms, 64 (41.29\%) indicated it as their primary method with further eight firms $(5.16 \%)$ indicating that they use NPV analysis combined with real options analysis. However, even if we take both categories (46.45\%) into account, we find that the Nordic companies use the NPV method way less often that their U.S. counterparts. According to Graham and Harvey (2001), the NPV method was used by more than 74 percent of the U.S. companies. 
The payback period method was surprisingly commonly used, being the second most popular method (25.16\%) despite its theoretical problems. ${ }^{19}$ In the U.S., the payback rule is even more popular according to Graham and Harvey (2001). They found that firms used it always or almost always in 55 percent of the companies. The next popular methods in our study were the internal rate of return $(19.35 \%)$ as well as accounting measures and earnings multiples (both used by $17.42 \%$ of the respondents).

Analyzing secondary methods and methods used in special cases shows that almost all the methods were popular and used by the companies. The biggest overall difference between primary and secondary methods concerned the sensitivity analysis, which was the most popular secondary method together with the pay-back method.

\subsection{The required rate of return}

The respondents were also asked what their required rate of return for the whole company (WACC) was. An option to answer 'not calculated' was also offered. Table 3 reports the results. Out of 144 responses, a surprisingly high number of companies, 62 (43.1\%), answered that the WACC is not calculated for their company. The percentage of companies calculating the WACC $(56.9 \%)$ is clearly lower than what for example Meier and Tarhan (2007) found in their survey among the largest US companies (71.8\%). This could be due to the use of DCF techniques and the CAPM is lagging in the Nordic countries that when compared to the USA (c.f., Liljeblom and Vaihekoski 2007) or due to the use of different ways to define hurdle rates for the DCF-analysis.

The average WACC was 10.69 percent with a median of 10.00 percent. The highest WACC reported was 25.0 percent, and the minimum was 6.5 percent. Only three companies provided WACCs equal or higher than 20 percent, suggesting surprisingly low cross-sectional dispersion as suggested by the low volatility (3.31\%). Analyzing the results across different countries (not reported here), we found that the highest WACC was set by Norwegian companies $(12.13 \%)$ and the lowest by the Swedish companies (10.09\%). The difference is not statistically significant (a t-value of 0.96).

19 The payback method ignores for example the time value of money, cash flows beyond the cutoff date, and 
Our results differ slightly e.g. from Meier and Tarhan (2007) who found out that the mean WACC for the US companies within their sample was 14.1 percent with a median of 14.0. It is a clearly higher than what we found, but it could be partly explained by the different timing of the surveys (2003 vs. our 2007) as well as other differences in the samples.

In addition, we asked the companies to give more detailed information about the required rate of return. First, we asked how often the required rate of return changes. The results in Table 3 are partly conflicting, as 117 companies have responded to this question, even though 62 companies earlier indicated that they do not calculate WACC (which would have left at most 95 potential companies to answer this question). Since the question did not specifically relate the change to the WACC rather than "the rate of return", the high number of responses for this question could be interpreted as partial support for the hypothesis that firms may use ways other than the WACC to define their required (hurdle) rates.

Nevertheless, the overall results indicate that the companies update their targeted WACCs annually (52.5\% of the respondents). This is almost similar to what Liljeblom and Vaihekoski (2004) found for Finnish companies alone (60\%). Few companies (5.9\%) indicated that they do not at all update their required rate of return (or at least have not updated it so far). Surprisingly many companies (16.9\%) updated their WACC more frequently than once a year. $^{20}$

Second, we asked whether the length of an investment project affects the required rate of return. For close to half of the companies $(46.3 \%)$, the required rate of return can differ across different projects, even if they had an equally long time span. In 19.8 percent of the companies, the required rate stays the same for all projects, leaving 33.9 percent of the companies to fall in between these two groups, keeping the rate the same for most of the projects but not all of them. When asked whether the required rate of return increased with the length of the investment project, the high majority $(82.8 \%)$ of the respondents answered that it did not increase, 11.8 percent indicated that the required rate of return was higher for longer projects,

there is no clear decision criterion to determine whether or not to invest.

20 We also calculated the frequency only for those companies who provided their WACC. The results are very similar. 
and 2.2 percent that it actually was lower. The results are partly conflicting with the finance literature, as many books seem to advocate higher required rates for longer investment projects in order to account for the higher risk involved with cash flows that stretch far into the future.

Finally, we also asked the respondents a detailed question on how they set the required rate of return for individual investment projects. Again the respondents were given a chance to indicate one primary method, and several secondary and on a case-by-case basis used methods from a list of alternative methods which included an option to answer that no required rate of return was set nor no method used. Table 4 reports the results.

Almost one third of the respondents (29.41\%) use the WACC, which they have for the whole company, also for different investment projects. Almost as many companies adjust their WACC for the project's risk (26.14\%). Only a few companies adjust their WACC for the division's risk $(3.27 \%)$ or country's risk $(5.23 \%)$. These results partly in line with what Graham and Harvey (2001) found, using a partly different set of questions. They found that 58.79 percent $(50.95 \%)$ of the companies always, or almost always, also for their projects use the discount rate for the entire company (a risk matched discount rate for the particular project). However, surprisingly many companies base investments' required rate purely on project's risk $(13.73 \%)$ or on the equity and debt mix used to finance the project $(9.15 \%){ }^{21}$

\section{THE DETERMINANTS OF CAPITAL BUDGETING METHODS}

\subsection{Determinants of the main capital budgeting method}

In this section, we analyze the determinants of the main capital budgeting method used by the firms. Table 5 reports results from robust probit models where the choice of NPV is regressed on country and sector dummies, firm size, variables proxying for real options and agency

21 We also asked about the setting of the rate for equity (not reported here). Contrary to Liljeblom and Vaihekoski (2004), who found that a bit more than a quarter of the companies $(27.3 \%)$ admit that no required rate of return set is set for the equity, only 14.4 percent of the respondents gave the same answer. Forty-five companies $(29.03 \%)$ answered that the rate of return is set by the top management. Versions of the CAPM (i.e. the basic CAPM or versions potentially including additional risk factors) were chosen by 34.6 percent of the companies. Analyzing the result country-wise, we find that versions of the CAPM are most common in Finland (used by 54.2 of the responding firms), then in Norway (37.5\%), Denmark $(31.3 \%)$, Sweden $(28.2 \%)$, and finally Iceland (16.7\%). 
problems, and finally also on other variables such as CFO_pressure and CFO characteristics. The model is:

$$
\begin{aligned}
& N P V_{-} \text {as } \text { primary }_{i}= \\
& \quad \lambda_{0}+\lambda_{1}(C D)_{i}+\lambda_{2}(S D)_{i}+\lambda_{3}(\text { Ln_ sales })_{i}+\lambda_{4}(R O)_{i}+\lambda_{5}(A C)_{i}+\lambda_{5}(\text { Other })_{i}+e_{i}
\end{aligned}
$$

where $C D_{i}$ stand for three country dummies (DEN, FIN, and SWE for Denmark, Finland and Sweden, Norway and Iceland being left to be captured by the intercept), $S D_{i}$ represents two sector dummies (FIN_SEC and IND_SEC, for the financial and industrial sectors), Ln_sales is the firm's past annual sales, $R O_{i}$ is a variable trying to capturing the existence of real options (Past_Growth, and ROA), $A C_{i}$ is a vector of variables proxying for agency costs and firm complexity (OWN_largest, and SIC), and Other is a vector of variables for the CFO's shortterm pressure, and CFO characteristics (age and economic / business education).

Table 5 reports the results of different robust probit estimations, testing the determinants of NPV as a primary model. The results from column 1 show that there are significant differences between countries in the use of NPV as a primary method. Finland and Sweden obtain negative coefficients (which in the later specifications in Table 5, sometimes are significant), whereas the method is significantly more common in Denmark as compared to the countries without a country dummy (Norway and Iceland). The financial sector also obtains a significant coefficient in column 1 .

In column two of Table 5, we have extended the model by including all but the CFO characteristics. In line with previous studies, size is a significant determinant of the sophistication of capital budgeting, exemplified here as a significantly more common use of the NPV method as a primary tool. We also obtain the expected negative sign for ROA as a proxy for real options and a less frequent use of the NPV as the primary method (whereas the other proxy for real options, Past_Growth, is insignificant and with a sign different from expectations). Finally, OWN_largest is significant but with a negative sign. This result goes against the prediction by Berkovitch and Israel (2004). Since our other agency cost variable, SIC, obtains the expected negative sign but is insignificant, we also estimate a new version of the model, adding the variable Large_and_div. This specification, reported in column three, 
allows a test of the linearity of SIC i.e. whether firm complexity influences the use of NPV differently in different size categories. The new specification strengthens the basic SIC but not enough to gain significance.

Columns four and five of Table 5 test the effect of CFO characteristics on the use of NPV. CFO_age and CFO_econ_edu both obtain the expected signs but are not quite significant in column four. When CFO age is replaced by a dummy for CFOs older than 50 years, the variable is significant at the $5 \%$ level in column five, indicating that NPV is less often used by such firms.

Next, we test determinants of the "sophistication" of capital budgeting in our respondent firms. As dependent variables we use the sophistication indexes described in section four. Our model is otherwise identical to that of (1), and to the specification in column 4 of Table 5 , but now with a different dependent variable (Index_1 to Index_4 in different specifications). Since our dependent variable is a discrete one, we estimate robust ordered probit models. Table 6 reports these results.

The results in Table 6 are mainly in line with our previous findings. The use of more sophisticated methods is significantly positively related to firm size, and negatively to ROA and OWN_largest. When we move to more sophisticated methods, the positive relationship to the CFO having an economic education grows in significance.

The results in this section support earlier findings on the use of NPV, and using more sophisticated methods, i.e. that such use is more common in larger firms. We also get support for ROA as a real option proxy, i.e. that in more profitable firms, the use of methods other than the NPV is more common. Surprisingly, firms controlled by large owners also use NPV significantly less often. Since ownership levels in the Nordic countries are often very high, this may be a sign of an entrenchment effect (agency problems between the large owner and other owners) in such firms. Alternatively, the sophistication level and / or the preferences of the large owners may play in. Finally, we find that the sophistication level of capital budgeting methods is increasing in the CFO's economic / business education. 


\subsection{Determinants of the hurdle rate}

Next, we study the determinants of the hurdle rate premium. Our estimated WACC_theor is on average $6.68 \%$ (with a standard deviation of 1.75), i.e. much lower than the reported WACC_survey's. The estimated hurdle rate premium (WACC_prem) has a mean of 3.99\%, and ranges from $-4.12 \%$ to $+18.92 \%$. The average premium is significantly in excess of zero (a t-value of 8.95), and would be so also in case we would use a 2 percent units higher corporate bond yield together with a two percent units higher equity premium. Figure 2 shows its distribution. Our estimates for the hurdle rate premium are close to those by Meier and Tarhan (2007) for the U.S. Assuming an equity premium of $6.6 \%$ (3.6\%), they obtained in their monthly model averages of $5.28 \%(7.45 \%)$, with a range between $-6.96 \%$ and $21.07 \%(0.51 \%$ and $27.71 \%)$.

Our model is similar to model (1), now only using WACC_prem, the difference between the survey WACC and the theoretical WACC, as dependent variable:

$$
\begin{aligned}
& \text { WACC_prem } \\
& \lambda_{0}+\lambda_{1}(C D)_{i}+\lambda_{2}(S D)_{i}+\lambda_{3}\left(\text { Ln_ }_{-} \text {sales }\right)_{i}+\lambda_{4}(R O)_{i}+\lambda_{5}(A C)_{i}+\lambda_{5}(\text { Other })_{i}+e_{i}
\end{aligned}
$$

where $C D_{i}$ stand for three country dummies (DEN, FIN, and SWE for Denmark, Finland and Sweden, Norway and Iceland being left to be captured by the intercept), $S D_{i}$ represents two sector dummies (FIN_SEC and IND_SEC, for the financial and industrial sectors), Ln_sales is the firm's past annual sales, $R O_{i}$ is a variable trying to capturing the existence of real options (Past_Growth, and ROA), $A C_{i}$ is a vector of variables proxying for managerial agency costs (OWN_largest, and SIC), and Other ${ }_{i}$ is a vector of variables for the CFO's short-term pressure, and CFO characteristics (age and economic education). To test for a relationship between the use of sophisticated capital budgeting methods (analyzed in section 6.1 of the paper), and a hurdle rate premium analyzed here, we also include Index_4 in a final version of the model.

The results for model (2) are reported in Table 7. In column 1, where only the country and sector dummies are included, there are signs of significant country and sector differences. The country dummies are all negative, and significant differences from the countries left without a 
dummy are detected for Denmark (at the 10\% level) and Sweden (at the $1 \%$ level). The dummy for the financial sector is also significant at the $5 \%$ level, indicating a higher hurdle rate premium. However, when additional explanatory variables are added, the significance levels go down. Only in model 4, where the measure of capital budgeting sophistication, Index_4, is included, that variable is significant together with $\mathrm{CEO}$-pressure. The latter indicates that hurdle rates are higher in firms where the CFO experiences a larger pressure for short-term results, i.e. a result in line with Liljeblom and Vaihekoski (2009) for Finland. The significance of Index_4 in turn implies that firms using more sophisticated capital budgeting methods also use more modest hurdle rates (and firms with less sophisticated models thus on average use higher hurdle rates). This result goes in line predictions from both the real options as well as agency cost categories, since explanations from both categories combine the use of higher hurdle rates with a higher use of multiple methods and "rules of thumb". ${ }^{22}$

\section{CONCLUSIONS}

Using survey data for five Nordic countries, we study the determinants for the choice of capital budgeting methods and the hurdle rate (WACC) in investment evaluation. We contribute to prior studies through the use of a broader set of explanatory variables, based on real options, agency problems as well as CFO characteristics. Beside CFO age and education, we test a novel variable in this setting, the pressure that the CFO feels for producing a good result in the short-term.

We find that the use of discounted cash-flow methods, especially the NPV, is still much less common in the Nordic countries as compared to the U.S. According to our survey responses, NPV is chosen as one of the main methods in $41.29 \%$ of the cases (and $5.16 \%$ used NPV analysis combined with real options), whereas Graham and Harvey (2001) found, much earlier, that the NPV method was used by more than $74 \%$ of the U.S. companies. The second most common method in our survey is the pay-back method (used in $25.16 \%$ of the companies).

22 Index 4 also turns out to be the clearly most important determinant for the hurdle rate premium. Robustness tests reveal that it is highly significant (mostly the $1 \%$ level) in all specifications for WACC_prem, starting from a single regression. Also the other sophistication measures (Index_1 to Index_3), and even NPV_as_primary, produce similar results when included as explanatory variables for WACC_prem. The correlation between these range from 0.78 (Index_4 and NPV_as_primary) to 0.99 (Index_1 and Index_2). 
When studying the determinants for the choice of NPV as a primary method, we find support for variables relating to real options (return-on-assets as a proxy for growth options), but we also find that the presence of a large owner, contradictory to our expectations, significantly reduces the likelihood for NPV use. We also find support for influences from CFO characteristics: NPV is significantly less often used in firms where the CFO is older than 50 years.

Using the survey responses to questions related to the choice of the capital budgeting method, and the hurdle rate for projects, we create several (highly correlated) proxies for the sophistication of the capital budgeting in the firm. As determinants for such indexes, we find support for the same variables as before (ROA and the presence of a large owner, both with a negative impact), but we also find that the sophistication of capital budgeting is increasingly (when moving to broader indexes) related to the CFO having an education in economics / business.

Finally we study the setting of the hurdle rate. We thereby contribute to the literature concerning the "hurdle rate puzzle", i.e. the empirical observation that the hurdle rates (WACCs) used by firms tend to be higher than those suggested by economic theory. We contrast the WACC rates obtained from the survey by "theoretical" hurdle rates constructed by ourselves on the basis of the CAPM, and empirical inputs for the return on equity and debt, empirical tax rates, and the firm's capital structure. The difference between these two rates (the WACC premium) ranges between $-4 \%$ and $+19 \%$, with a mean of $4 \%$, which is close to that found by Meier and Tarhan (2007). When studying the determinants for the hurdle premium, we find weak support for the pressure felt by the CFO as a positive determinant. This result is in line with Liljeblom and Vaihekoski (2009), who find support for a relationship between the owners of a firm (more short-term or long-term oriented owners), and their choice of capital budgeting methods (a higher WACC and a shorter pay-back time being used by firms with more short-term owners). We also find a significant relationship between our proxies for the sophistication of the capital budgeting, and the hurdle rate premium: higher hurdle rates are used by firms which score lower in the sophistication index. 


\section{REFERENCES}

Anand, M., 2004, A review of research on the practices of corporate finance, South Asian Journal of Management 11, 59-95.

Berkovitch, E., Israel, R., 2004, Why the NPV Criterion does not Maximize NPV, Review of Financial Studies 17, 239-255.

Bierman, H. J., 1993, Capital budgeting in 1992: A survey, Financial Management 22, 24.

Brigham, E.F., 1975, Hurdle rates for screening capital expenditure proposals, Financial Management 4, 17-26.

Brounen, D., De Long, A., Koedijk, K., 2004, Corporate finance in Europe: Confronting theory with practice, Financial Management 33, 71-101.

Brunzell, T., Liljeblom, E., Vaihekoski, M., 2009, Short-term expectations in listed firms: The mitigating impact of large owners. Unpublished working paper. Available at http://ssrn.com/abstract=1400734.

Fernandez, P., del Campo, J., 2010, Market risk premium used in 2010 by professors: a survey with 1,500 answers. Unpublished working paper, available at http://ssrn. com/abstract $=1606563$.

Gitman, L. J., Forrester, J. R., 1977, A survey of capital budgeting techniques used by major U.S. firms, Financial Management 6, 66-71.

Gitman, L.J., Mercurio, V.A., 1982, Cost of capital techniques used by major U.S. firms: survey and analysis of Fortune's 1000, Financial Management, 21-29.

Graham, J. R., Harvey, C. R., 2001, The theory and practice of corporate finance. Journal of Financial Economics 60, 187-243.

Graham, J. R., Harvey, C. R., 2002, How do CFOs make capital budgeting and capital structure decisions? Journal of Applied Corporate Finance 15, 1, 8-23.

Graham, J. R., Harvey, C. R. and Rajgopal, S., 2006, Value Destruction and Financial Reporting Decisions. Financial Analyst Journal 62, 27-39.

Hermes, N., Smid, P., Yao, L., 2005, Capital budgeting practices: a comparative study of the Netherlands and China, working paper, University of Groningen.

Holmén, M., Pramborg, B., 2006, Capital budgeting and political risk: empirical evidence, Journal of International Financial Management \& Accounting 20, 105-134.

Jagannathan, R., Meier, I., 2002, Do we need CAPM for capital budgeting? Financial Management 31, 55-77.

Klammer, T., 1972, Empirical evidence of the adoption of sophisticated capital budgeting techniques, Journal of Business 45, 387-397.

Liljeblom, E., 2008, Economic General Report, in Påhlsson R. (ed.), Taxation of capital and wage income: towards separated or more integrated personal tax systems? Yearbook For Nordic Tax Research 2008, Djøf publishing, Copenhagen. 
Liljeblom, E., Vaihekoski, M., 2009, Corporate Ownership and Managerial Short-Termism: Results from a Finnish Study of Management Perceptions. International Journal of Production Economics 117, 427-438.

Liljeblom, E., Vaihekoski, M., 2004, Investment Evaluation Methods and Required Rate of Return in Finnish Publicly listed Companies. Finnish Journal of Business and Economics 54, 9-24.

McDonald, R. L., 2000, Real options and rules of thumb in capital budgeting. In Brennan M.J. and Trigeorgis L. (Eds.), Project flexibility, agency and competition: new developments in the theory and application of real options. Oxford University Press, New York.

McDonald, R.L., 2006, The role of real options in capital budgeting: theory and practice, Journal of Applied Corporate Finance 18, 28-39.

Magni, C. A., 2008, CAPM-based capital budgeting and nonadditivity, Journal of Property Investment and Finance 26, 388-398.

Martin, J., 2008, Single vs. multiple discount rates: how to limit "influence costs" in the capital allocation process, Journal of Applied Corporate Finance 20, 79-83.

Meier, I., Tarhan, V., 2007, Corporate investment decision practices and the hurdle rate premium puzzle. Unpublished working paper. http://ssrn.com/abstract=960161

Miller, R. A., 2009, The weighted average cost of capital is not quite right, The Quarterly Review of Economics and Finance 49, 128-138.

Payne, J.D., Carrington Heath, W., Gale, L. R., 1999, Comparative financial practice in the US and Canada: Capital budgeting and assessment techniques, Financial Practice and Education 9, 16-24.

Pierru, C. A., 2009, 'The weighted average cost of capital is not quite right': A comment, The Quarterly Review of Economics and Finance 49, 1219-1223.

Poterba, J. M., Summers, L. H., 1995, A CEO survey of U.S. companies' time horizon and hurdle rates, Sloan Management Review 37, 43-53.

Sandahl, G., Sjögren, S., 2003, Capital budgeting methods among Sweden's largest groups of companies. The state of the art and a comparison with earlier studies. International Journal of Production Economics 84, 51-69.

Stanley, M. T., Block, S. B., 1984, A survey of multinational capital budgeting, The Financial Review 19, 36-54. 
APPENDIX 1. The questions from the survey included in this study.

1. Short-term external expectations:

To what extent do You feel that short-term external expectations conflict with Company's

long-term goals?

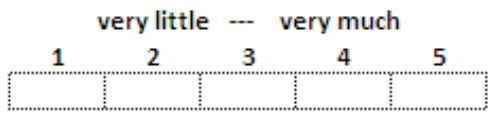

2. Please estimate Your Company's average

annual turnover growth from 2008 to 2012 (five years).

$\%$

3. What investment criteria do You use for investment evaluation?

Please provide only one primary measure. You may list a number of secondary measures

and/or special cases.

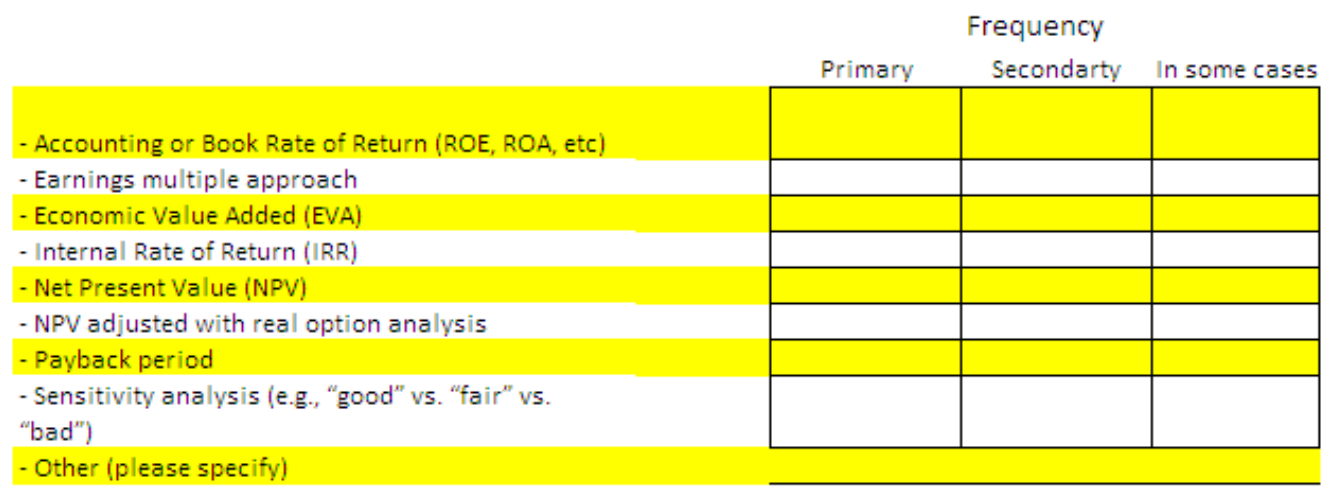

4. Please reply concerning the required rate of return for Your whole Company. List the most correct alternative.

What is Your required rate of return for the whole Company (WACC)?

Not calculated

How often does the rate of return change?

\begin{tabular}{|c|c|c|c|}
\hline Never & $\begin{array}{c}\text { Not } \\
\text { every year }\end{array}$ & $\begin{array}{c}\text { Once } \\
\text { a year }\end{array}$ & $\begin{array}{c}\text { More } \\
\text { frequently }\end{array}$ \\
\hline & & & \\
\hline
\end{tabular}

Is the rate of return the same for all projects that are equally long?

\begin{tabular}{|c|l|l|}
\hline Yes & $\begin{array}{c}\text { In } \\
\text { most cases }\end{array}$ & $\begin{array}{c}\text { No, } \\
\text { it can differ }\end{array}$ \\
\hline & & \\
& & \\
\hline
\end{tabular}

The rate of return for the same investment projects but with different lenghts is:

\begin{tabular}{|l|l|l|}
\hline Higher & Same & Lower \\
\hline & & \\
& & \\
\hline
\end{tabular}

5. What method do you use determine the required rate of return for their investment projects? Please provide only one primary measure. You may list a number of secondary mea sures as well as measures for some special cases.

- Not set / no method used

- Same as for the whole company (W ACC)

- W ACC adjusted by project's risk

- W ACC adjusted by division's risk

- WACC adjusted by country's risk

- Based totally on project's risk

to finance the project

\begin{tabular}{|l|l|l|l|l|}
\hline \multicolumn{3}{|l|}{ Frequency } & & \\
\hline Primary & Secondary & In some cases & \\
\hline & & & & \\
\hline & & & & \\
\hline & & & & \\
\hline & & & & \\
\hline & & & & \\
\hline & & & & \\
\hline & & & \\
\hline
\end{tabular}




\section{APPENDIX 2. Variable definitions}

Descriptions of the variables used in the analyses. Financial statement data is from Amadeus, complemented by data from Datastream and annual reports for the firms. Stock return and price data are obtained from the Datastream, while SIC codes are from Worldscope. Data on the largest shareholder (blockholder) is from Amadeus, while management ownership data is from annual reports. All data items are for the last reporting year (typically 2006) prior to the survey.

\begin{tabular}{ll}
\hline \hline Variable & Description \\
\hline \hline WACC_survey & $\begin{array}{l}\text { A survey response variable, the answer to a question concerning the } \\
\text { required rate of return for the whole company (WACC). }\end{array}$
\end{tabular}

\begin{tabular}{|c|c|}
\hline WACC_theor & $\begin{array}{l}\text { A "theoretical" WACC for the firm. The return on equity is based on the } \\
\text { CAPM, with the following inputs: betas estimated using prior one-year } \\
\text { stock returns and local market indexes; ten-year local currency government } \\
\text { bond yields as the risk-free rate; an expected equity risk premium of } 5 \% \text {. } \\
\text { As the return on debt, we use the ten-year local currency government bond } \\
\text { yields plus a hypothetical margin of one percent. Market values of equity } \\
\text { and book values of debt are used to calculate weights for equity and debt, } \\
\text { and the tax rates are based on the actual (flat) tax rates in the Nordic } \\
\text { countries. }\end{array}$ \\
\hline WACC_prem & The difference between WACC_survey and WACC_theor. \\
\hline NPV_as_primary & $\begin{array}{l}\text { A dummy that takes the value of one if the firm has responded that they } \\
\text { use the NPV method as one of their primary methods }\end{array}$ \\
\hline Index_1 & $\begin{array}{l}\text { A sum of three scores, each taking the value of one if the firm uses the } \\
\text { method in question. These methods are: a discounted cash flow method, } \\
\text { a discounted cash flow method as a primary method, and NPV as a } \\
\text { primary method. }\end{array}$ \\
\hline Index_2 & $\begin{array}{l}\text { A sum of Index_1 and a binary variable taking the value of } 1 \text { is the firm } \\
\text { has indicated that they change their WACC over time. }\end{array}$ \\
\hline Index_3 & $\begin{array}{l}\text { A sum of Index_2 and a binary variable, taking the value of one if the } \\
\text { firm uses different WACCs for different projects. }\end{array}$ \\
\hline Index_4 & $\begin{array}{l}\text { A sum of Index_3 and a binary variable, taking the value of one if the } \\
\text { firm uses different WACCs for projects otherwise identical but with a } \\
\text { different length. }\end{array}$ \\
\hline Past_Growth & Percentage change in total sales between past two years. \\
\hline Ln_sales & Ln (turnover), where turnover measured in 1000 euros \\
\hline ROA & Net profit / total assets. \\
\hline OWN_largest & The percent of equity owned by the largest owner. \\
\hline SIC & $\begin{array}{l}\text { A measure for firm level diversification, calculated as the number of } \\
\text { different sic-codes for the firm at the } 2^{\text {nd }} \text { digit level. }\end{array}$ \\
\hline Large_and_div & $\begin{array}{l}\text { An interaction variable which is a product of a dummy for firms with } \\
\text { sales exceeding } 1 \text { billion euros, and SIC. }\end{array}$ \\
\hline CFO_pressure & $\begin{array}{l}\text { A survey response variable, based on the CFO's reply on the question 'to } \\
\text { what extend do you feel that short-term external expectations conflict } \\
\text { with company's long-term goals?' with given alternatives } 1 \text { (very little) to } \\
5 \text { (very much). }\end{array}$ \\
\hline CFO_age & The age of the CFO. \\
\hline CFO_above 50 & $\begin{array}{l}\text { An indicator variable that takes the value of one if the CFO is } 50 \text { years or } \\
\text { older, and zero otherwise. }\end{array}$ \\
\hline CFO_econ_edu & $\begin{array}{l}\text { A dummy that takes the value of one if the CFO has an MBA or a } \\
\text { university degree in economics / management, and zero otherwise. }\end{array}$ \\
\hline SWE, FIN, DEN & $\begin{array}{l}\text { Dummies for Sweden, Finland, and Denmark.. Norway and Iceland are } \\
\text { without a dummy. }\end{array}$ \\
\hline FI_SEC, IND_SEC & $\begin{array}{l}\text { Dummies for financial and industrial sectors, taking the value of } 1 \text { if the } \\
\text { firm belongs to the sector in question, and zero otherwise. }\end{array}$ \\
\hline
\end{tabular}




\section{APPENDIX 3. Descriptive statistics for key variables}

Descriptive statistics (mean, median, standard deviation, minimum and maximum values, and the number of observations) for key variables in the study. For variable definitions, see Appendix 2. Because the responding firms in the survey were promised anonymity, we do not report individual firm specific statistics such as the MIN and MAX values for firm financials nor CFO characteristics.

\begin{tabular}{|c|c|c|c|c|c|}
\hline Variable & Mean & Median & St.dev. & MIN & MAX \\
\hline WACC_survey & 10.6939 & 10 & 3.3102 & 25 & 6.5 \\
\hline WACC_theor & 6.6830 & 6.4889 & 1.7512 & 13.1154 & 3.9941 \\
\hline WACC_prem & 3.9880 & 3.3977 & 4.0610 & 18.9227 & -4.1154 \\
\hline NPV_as_primary & 0.4452 & 0 & 0.4986 & 1 & 0 \\
\hline Index_1 & 1.8903 & 2 & 1.1199 & 3 & 0 \\
\hline Index_2 & 2.6000 & 3 & 1.2772 & 4 & 0 \\
\hline Index_3 & 3.2258 & 3 & 1.5013 & 5 & 0 \\
\hline Index_4 & 3.7484 & 4 & 1.7603 & 6 & 0 \\
\hline LN_sales & 11.7930 & 11.9278 & 2.8056 & & \\
\hline ROA & 3.9138 & 5.87 & 17.5635 & & \\
\hline Past_Growth & 0.8701 & 0.15435 & 6.65889 & & \\
\hline Large_owner & 26.3227 & 22.4 & 18.8512 & & \\
\hline SIC & 2.1401 & 2 & 1.3178 & 7 & 1 \\
\hline Large_and_div & 0.5839 & 0 & 1.2950 & 5 & 0 \\
\hline CFO_pressure & 2.73 & 3 & 1.0691 & 5 & 1 \\
\hline CFO_age & 45.1409 & 45 & 7.0854 & & \\
\hline CFO_above_50 & 0.2618 & 0 & 0.4411 & 1 & 0 \\
\hline CFO_econ_edu & 0.9110 & 1 & 0.2858 & 1 & 0 \\
\hline
\end{tabular}




\section{Table 1. Descriptive statistics for responding firms and target population}

Descriptive statistics are reported for responding firms (the "Sample", a total of 157 firms), i.e. firms from which we received filled-in CFO questionnaire. Our sample is compared to the firms listed at the main lists in Denmark, Finland, Iceland, Norway and Sweden at the time of the surveys (a total of 780 firms, when off-shore firms and ADRs are excluded). The firms are divided into Financials (banks, investment and insurance companies) and Non-financials, based on the sector codes used by the OMX exchanges and Oslo Børs (both use same ten categories). We report averages, medians, standard deviations, and the number of firms for which the financial information item has been obtained ("Obs"), for the following variables: Turnover (in 1000 euros), No. of employees, Total assets (in 1000 euros), Return on total assets (ROA, defined as Net Profit to Total Assets) and Solidity (defined as Equity to Total Assets). Financial data is for the last available reporting year prior to the date for sending out the questionnaire (typically 2007 for Norway, and 2006 for the others), and has been collected from Amadeus, Datastream, and annual reports for the companies.

\begin{tabular}{|c|c|c|c|c|c|}
\hline & & \multicolumn{2}{|c|}{ Non-financials } & \multicolumn{2}{|c|}{ Financials } \\
\hline & & Sample & sted & Sample & All listed \\
\hline \multicolumn{2}{|l|}{ Firms } & 129 & 615 & 28 & 165 \\
\hline \multirow{4}{*}{$\begin{array}{l}\text { Turnover, } \\
1000 \text { EUR }\end{array}$} & Mean & 1889846 & 1058814 & 1344601 & 543775 \\
\hline & Median & 139076 & 101826 & 210831 & 53981 \\
\hline & St.dev. & 6189753 & 3939259 & 2890638 & 2039941 \\
\hline & Obs & 127 & 604 & 23 & 142 \\
\hline \multirow{4}{*}{$\begin{array}{l}\text { No of } \\
\text { exployees }\end{array}$} & Mean & 6839 & 4405 & 2885 & 1520 \\
\hline & Median & 625 & 396 & 247 & 135 \\
\hline & St.dev. & 23025 & 22460 & 6504 & 4679 \\
\hline & Obs & 122 & 569 & 25 & 139 \\
\hline \multirow{4}{*}{$\begin{array}{l}\text { Total assets, } \\
1000 \text { EUR }\end{array}$} & Mean & 1752314 & 1049915 & 25396129 & 12379270 \\
\hline & Median & 134769 & 102364 & 1949728 & 570934 \\
\hline & St.dev. & 5619622 & 3696905 & 72402303 & 53042764 \\
\hline & Obs & 129 & 615 & 28 & 165 \\
\hline \multirow{4}{*}{$\begin{array}{l}\text { ROA, } \\
\text { per cent }\end{array}$} & Mean & 3.18 & 4.22 & 7.31 & 5.95 \\
\hline & Median & 5.99 & 6.40 & 4.39 & 2.40 \\
\hline & St.dev. & 18.94 & 16.28 & 8.21 & 9.64 \\
\hline & Obs & 129 & 613 & 28 & 162 \\
\hline \multirow{4}{*}{$\begin{array}{l}\text { Solidity, } \\
\text { per cent }\end{array}$} & Mean & 48.81 & 49.07 & & \\
\hline & Median & 45.34 & 45.58 & & \\
\hline & St.dev. & 20.24 & 20.11 & & \\
\hline & Obs & 127 & 610 & & \\
\hline
\end{tabular}




\section{Table 2. The investment evaluation methods}

The relative frequency of different investment criterion is given in the table. Column $\mathrm{N}$ (firms) indicates how many companies (out of the total of 155 responding companies) chose the given methods as their primary, secondary, or occasional investment evaluation criteria. Columns labeled as "N" and "\% of firms" indicate the relative frequency (percentage of firms) of the given method in companies (out of the total). The respondents could choose several methods as their primary, secondary or occasional investment evaluation method. The first row indicates the total number of methods chosen. Columns labeled as "\% of responses" indicate the relative frequency of the given method among all methods in each category. The total number of companies (N) answering this question was 155 .

\begin{tabular}{|c|c|c|c|c|c|c|c|c|c|c|}
\hline \multirow[b]{2}{*}{ Criteria } & \multirow[b]{2}{*}{$\mathrm{N}$ (firms) } & \multicolumn{3}{|c|}{ Primary } & \multicolumn{3}{|c|}{ Secondary } & \multicolumn{3}{|c|}{ In some cases } \\
\hline & & $\mathrm{N}$ & $\begin{array}{l}\% \text { of } \\
\text { firms }\end{array}$ & $\begin{array}{c}\% \text { of } \\
\text { responses }\end{array}$ & $\mathrm{N}$ & $\begin{array}{c}\% \text { of } \\
\text { firms }\end{array}$ & $\begin{array}{c}\% \text { of } \\
\text { responses }\end{array}$ & $\mathrm{N}$ & $\begin{array}{l}\% \text { of } \\
\text { firms }\end{array}$ & $\begin{array}{c}\% \text { of } \\
\text { responses }\end{array}$ \\
\hline $\mathrm{N}$ (criteria chosen) & 155 & 219 & & $100.00 \%$ & 295 & & $100.00 \%$ & 159 & & $100.00 \%$ \\
\hline $\begin{array}{l}\text { Accounting or Book Rate of Return } \\
\text { (ROE, ROA etc.) }\end{array}$ & 82 & 27 & $17.42 \%$ & $12.33 \%$ & 31 & $20.00 \%$ & $10.51 \%$ & 24 & $15.48 \%$ & $15.09 \%$ \\
\hline Earnings multiple & 81 & 27 & $17.42 \%$ & $12.33 \%$ & 29 & $18.71 \%$ & $9.83 \%$ & 25 & $16.13 \%$ & $15.72 \%$ \\
\hline Economic Value Added (EVA) & 61 & 6 & $3.87 \%$ & $2.74 \%$ & 28 & $18.06 \%$ & $9.49 \%$ & 27 & $17.42 \%$ & $16.98 \%$ \\
\hline Internal Rate of Return (IRR) & 86 & 30 & $19.35 \%$ & $13.70 \%$ & 41 & $26.45 \%$ & $13.90 \%$ & 15 & $9.68 \%$ & $9.43 \%$ \\
\hline Net Present Value (NPV) & 119 & 64 & $41.29 \%$ & $29.22 \%$ & 38 & $24.52 \%$ & $12.88 \%$ & 17 & $10.97 \%$ & $10.69 \%$ \\
\hline $\begin{array}{l}\text { NPV adjusted with real options } \\
\text { analysis }\end{array}$ & 43 & 8 & $5.16 \%$ & $3.65 \%$ & 14 & $9.03 \%$ & $4.75 \%$ & 21 & $13.55 \%$ & $13.21 \%$ \\
\hline Payback period & 107 & 39 & $25.16 \%$ & $17.81 \%$ & 57 & $36.77 \%$ & $19.32 \%$ & 11 & $7.10 \%$ & $6.92 \%$ \\
\hline Sensitivity analysis & 90 & 14 & $9.03 \%$ & $6.39 \%$ & 57 & $36.77 \%$ & $19.32 \%$ & 19 & $12.26 \%$ & $11.95 \%$ \\
\hline Other & 4 & 4 & $2.58 \%$ & $1.83 \%$ & 0 & $0.00 \%$ & $0.00 \%$ & 0 & $0.00 \%$ & $0.00 \%$ \\
\hline
\end{tabular}




\section{Table 3. The company's required rate of return}

The respondents were asked a number a questions regarding the required rate of return for the whole company. The relative frequency of the answers as well as the number of answers $(\mathrm{N})$ is given in the table. The total number of companies participating in the survey was 46.

\begin{tabular}{lrr}
\hline \hline QUESTION & \% & N \\
\hline What is your required rate of return for the whole & & \\
company (WACC) & $10.69 \%$ & 84 \\
$\quad$ Mean & $3.31 \%$ & \\
$\quad$ Standard deviation & $10.00 \%$ & 61 \\
$\quad$ Median & & \\
$\quad$ Not calculated & $5.9 \%$ & 7 \\
How often does it change? & $23.7 \%$ & 28 \\
$\quad$ Never & $52.5 \%$ & 62 \\
$\quad$ Not every year & $16.9 \%$ & 20 \\
$\quad$ Once a year & & \\
$\quad$ More frequently & $19.8 \%$ & 24 \\
Is it the same for all projects, if project are equally & $33.9 \%$ & 41 \\
long? $\quad 46.3 \%$ & 56 \\
$\quad$ Yes & & \\
$\quad$ In most cases & & 11 \\
$\quad$ No, it can differ & $11.8 \%$ & 77 \\
Is it the same for investment projects of different & $82.8 \%$ & $2.2 \%$ \\
length? & & \\
$\quad$ Higher for longer projects & & \\
$\quad$ Same (length does not matter) & & \\
$\quad$ Lower for longer projects &
\end{tabular}




\section{Table 4. The required rate of return for investment projects}

The relative frequency of different methods to decide the required rate of return for investment projects is given in the table. Column $\mathrm{N}$ (firms) indicates how many companies (out of the total of 155 responding companies) chose the given methods as their primary, secondary, or occasional investment evaluation criteria. Columns labeled as "N" and "\% of firms" indicate the relative frequency (percentage of firms) of the given method in companies (out of the total). The respondents could choose several methods as their primary, secondary or occasional investment evaluation method. The first row indicates the total number of methods chosen. Columns labeled as "\% of responses" indicate the relative frequency of the given method among all methods in each category. The total number of companies (N) answering this question was 155 .

\begin{tabular}{|c|c|c|c|c|c|c|c|c|c|c|}
\hline \multirow[b]{2}{*}{ Criteria } & \multirow[b]{2}{*}{$\mathrm{N}$ (firms) } & \multicolumn{3}{|c|}{ Primary } & \multicolumn{3}{|c|}{ Secondary } & \multicolumn{3}{|c|}{ In some cases } \\
\hline & & $\mathrm{N}$ & $\begin{array}{l}\% \text { of } \\
\text { firms }\end{array}$ & $\begin{array}{l}\% \text { of } \\
\text { responses }\end{array}$ & $\mathrm{N}$ & $\begin{array}{l}\% \text { of } \\
\text { firms }\end{array}$ & $\begin{array}{l}\% \text { of } \\
\text { responses }\end{array}$ & $\mathrm{N}$ & $\begin{array}{l}\% \text { of } \\
\text { firms }\end{array}$ & $\begin{array}{l}\% \text { of } \\
\text { responses }\end{array}$ \\
\hline $\mathrm{N}$ (criteria given) & 155 & 153 & & & 77 & & & 31 & & \\
\hline Not set / no method used & 22 & 20 & $12.90 \%$ & $13.07 \%$ & 0 & $0.00 \%$ & $0.00 \%$ & 2 & $1.29 \%$ & $2.15 \%$ \\
\hline $\begin{array}{l}\text { Same as for the whole Company } \\
\text { (WACC) }\end{array}$ & 60 & 45 & $29.03 \%$ & $29.41 \%$ & 9 & $5.81 \%$ & $7.69 \%$ & 6 & $3.87 \%$ & $6.45 \%$ \\
\hline WACC adjusted by project's risk & 62 & 40 & $25.81 \%$ & $26.14 \%$ & 18 & $11.61 \%$ & $15.38 \%$ & 4 & $2.58 \%$ & $4.30 \%$ \\
\hline WACC adjusted by division's risk & 17 & 5 & $3.23 \%$ & $3.27 \%$ & 9 & $5.81 \%$ & $7.69 \%$ & 3 & $1.94 \%$ & $3.23 \%$ \\
\hline WACC adjusted by country's risk & 25 & 8 & $5.16 \%$ & $5.23 \%$ & 12 & $7.74 \%$ & $10.26 \%$ & 5 & $3.23 \%$ & $5.38 \%$ \\
\hline Based totally on project's risk & 44 & 21 & $13.55 \%$ & $13.73 \%$ & 16 & $10.32 \%$ & $13.68 \%$ & 7 & $4.52 \%$ & $7.53 \%$ \\
\hline $\begin{array}{l}\text { Based on the ratio of equity and } \\
\text { debt used to finance the project }\end{array}$ & 31 & 14 & $9.03 \%$ & $9.15 \%$ & 13 & $8.39 \%$ & $11.11 \%$ & 4 & $2.58 \%$ & $4.30 \%$ \\
\hline
\end{tabular}




\section{Table 5. Determinants of NPV as a primary method}

The table reports results from robust probit estimations where an indicator variable NPV_as_primary is regressed on country and sector dummies, logarithmic sales, past one year sales growth, return on assets i.e. ROA, OWN_largest (the percent of equity owned by the largest owner), SIC i.e. the number of SIC-codes for the firm at a two-digit level, Large_and_div, i.e. an interaction variable of SIC-codes for large firms, CFO pressure for short-term actions (a survey response variable) and CFO characteristics (CFO_age or CFO_age_above_50, and CFO_econ_edu). Coefficient estimates are reported on first row for each variable, followed by z.-value in parenthesis. Significant z-values at the $10 \%$ level are reported boldface. For variable definitions, see Appendix 2.

\begin{tabular}{|c|c|c|c|c|c|}
\hline Model & Model 1 & Model 2 & Model 3 & Model 4 & Model 5 \\
\hline \multirow[t]{2}{*}{ DEN } & 0.5532 & 0.7308 & 0.7905 & 0.5967 & 0.5963 \\
\hline & $(1.67)$ & $(\mathbf{1 . 8 6})$ & $(\mathbf{2 . 0 6})$ & $(1.25)$ & $(1.24)$ \\
\hline \multirow[t]{2}{*}{ FIN } & -0.5780 & -0.6391 & -0.5830 & -0.8617 & -0.8805 \\
\hline & $(-1.59)$ & $(-1.56)$ & $(-1.41)$ & $(-2.07)$ & $(-2.04)$ \\
\hline \multirow[t]{2}{*}{ SWE } & -0.3160 & -0.3047 & -0.2808 & -0.5044 & -0.5787 \\
\hline & $(-1.09)$ & $(-0.93)$ & $(-0.87)$ & $(-1.52)$ & $(-1.75)$ \\
\hline \multirow[t]{2}{*}{ FIN_SEC } & -0.6483 & -0.5808 & -0.5882 & -0.3619 & -0.4044 \\
\hline & $(-2.07)$ & $(-1.61)$ & $(-1.61)$ & $(-0.96)$ & $(-1.08)$ \\
\hline \multirow[t]{2}{*}{ IND_SEC } & -0.1297 & 0.0752 & 0.0773 & 0.2370 & 0.2024 \\
\hline & $(-0.53)$ & $(0.28)$ & $(0.28)$ & $(0.82)$ & $(0.69)$ \\
\hline \multirow[t]{2}{*}{ Ln_sales } & & 0.1805 & 0.1158 & 0.2039 & 0.1979 \\
\hline & & $(2.87)$ & $(1.56)$ & $(2.96)$ & (3.02) \\
\hline Past_Growth & & $\begin{array}{l}0.0437 \\
(0.63)\end{array}$ & $\begin{array}{l}0.0331 \\
(0.88)\end{array}$ & $\begin{array}{l}0.0320 \\
(1.54)\end{array}$ & $\begin{array}{c}0.0316 \\
(1.57)\end{array}$ \\
\hline \multirow[t]{2}{*}{ ROA } & & -0.0283 & -0.0244 & -0.0283 & -0.0272 \\
\hline & & $(-3.08)$ & $(-2.55)$ & $(-2.64)$ & $(-2.64)$ \\
\hline OWN_largest & & $\begin{array}{l}-0.0152 \\
(\mathbf{- 2 . 3 9})\end{array}$ & $\begin{array}{l}-0.0171 \\
(\mathbf{- 2 . 6 0})\end{array}$ & $\begin{array}{l}-0.0167 \\
(\mathbf{- 2 . 3 3})\end{array}$ & $\begin{array}{l}-0.0176 \\
(\mathbf{- 2 . 4 6 )}\end{array}$ \\
\hline \multirow[t]{2}{*}{ SIC } & & -0.0591 & -0.1123 & -0.0529 & -0.0736 \\
\hline & & $(-0.64)$ & $(-1.19)$ & $(-0.53)$ & $(-0.71)$ \\
\hline \multirow{2}{*}{ Large_and_div } & & & 0.1969 & & \\
\hline & & & $(1.53)$ & & \\
\hline \multirow[t]{2}{*}{ CFO_pressure } & & 0.0736 & 0.1069 & 0.0656 & 0.0286 \\
\hline & & $(0.68)$ & $(0.98)$ & $(0.57)$ & $(0.24)$ \\
\hline \multirow[t]{2}{*}{ CFO_age } & & & & -0.0307 & \\
\hline & & & & $(-1.60)$ & \\
\hline \multirow[t]{2}{*}{ CFO_age_above_50 } & & & & & -0.6136 \\
\hline & & & & & $(-1.98)$ \\
\hline \multirow[t]{2}{*}{ CFO_econ_edu } & & & & 0.5539 & 0.5862 \\
\hline & & & & $(1.32)$ & $(1.38)$ \\
\hline Obs $(\mathbf{N})$ & 155 & 138 & 138 & 129 & 129 \\
\hline Wald Chi ${ }^{2}$ & 16.00 & 28.30 & 35.21 & 30.50 & 36.09 \\
\hline Pseudo $\mathbf{R}^{2}$ & 0.0746 & 0.1591 & 0.1708 & 0.1957 & 0.2036 \\
\hline
\end{tabular}




\section{Table 6. Determinants of the sophistication of the capital budgeting method}

The table reports results from robust ordered probit estimations where an indicator variables for the sophistication of capital budgeting (Index_1 to Index_4) are regressed on country and sector dummies, logarithmic sales, past one year sales growth, return on assets i.e. ROA, OWN_largest (the percent of equity owned by the largest owner), SIC i.e. the number of SIC-codes for the firm at a twodigit level, CFO pressure for short-term actions (a survey response variable), and CFO characteristics (CFO_age, and CFO_econ_edu). Coefficient estimates are reported on first row for each variable, followed by z.-value in parenthesis. Significant z-values at the $10 \%$ level are reported boldface. For variable definitions, see Appendix 2.

\begin{tabular}{|c|c|c|c|c|}
\hline Model & Model 1 & Model 2 & Model 3 & Model 4 \\
\hline Dependent variable & Index_1 & Index_2 & Index_3 & Index_4 \\
\hline DEN & $\begin{array}{c}0.3440 \\
(0.80)\end{array}$ & $\begin{array}{c}0.4610 \\
(1.23)\end{array}$ & $\begin{array}{c}0.3966 \\
(1.02)\end{array}$ & $\begin{array}{c}0.5178 \\
(1.46)\end{array}$ \\
\hline FIN & $\begin{array}{l}-0.6244 \\
(-\mathbf{2 . 0 5})\end{array}$ & $\begin{array}{l}-0.4308 \\
(-1.37)\end{array}$ & $\begin{array}{l}-0.6537 \\
\mathbf{( - 2 . 0 7 )}\end{array}$ & $\begin{array}{l}-0.5418 \\
(\mathbf{- 1 . 8 2})\end{array}$ \\
\hline SWE & $\begin{array}{l}-0.5074 \\
(-\mathbf{1 . 8 8})\end{array}$ & $\begin{array}{l}-0.4397 \\
(-1.59)\end{array}$ & $\begin{array}{l}-0.5999 \\
(\mathbf{- 2 . 1 2})\end{array}$ & $\begin{array}{l}-0.5287 \\
(-\mathbf{2 . 0 0})\end{array}$ \\
\hline FIN_SEC & $\begin{array}{l}-0.0827 \\
(-0.26)\end{array}$ & $\begin{array}{l}-0.1950 \\
(-0.68)\end{array}$ & $\begin{array}{l}-0.2999 \\
(-1.02)\end{array}$ & $\begin{array}{l}-0.3242 \\
(-1.12)\end{array}$ \\
\hline IND_SEC & $\begin{array}{l}0.2432 \\
(1.04)\end{array}$ & $\begin{array}{l}0.0263 \\
(0.11)\end{array}$ & $\begin{array}{l}-0.0416 \\
(-0.16)\end{array}$ & $\begin{array}{l}-0.3319 \\
(-1.40)\end{array}$ \\
\hline In_sales & $\begin{array}{l}0.1151 \\
(\mathbf{2 . 3 2})\end{array}$ & $\begin{array}{l}0.1824 \\
(\mathbf{2 . 9 8})\end{array}$ & $\begin{array}{l}0.2077 \\
\mathbf{( 3 . 2 4 )}\end{array}$ & $\begin{array}{l}0.2160 \\
(\mathbf{3 . 7 2})\end{array}$ \\
\hline Past Growth & $\begin{array}{l}0.0239 \\
(\mathbf{1 . 8 7})\end{array}$ & $\begin{array}{c}0.0534 \\
(0.78)\end{array}$ & $\begin{array}{c}0.0746 \\
(0.85)\end{array}$ & $\begin{array}{c}0.0628 \\
(0.70)\end{array}$ \\
\hline ROA & $\begin{array}{l}-0.0167 \\
(\mathbf{- 1 . 8 2})\end{array}$ & $\begin{array}{l}-0.0196 \\
(\mathbf{- 2 . 4 3})\end{array}$ & $\begin{array}{l}-0.0214 \\
(-2.76)\end{array}$ & $\begin{array}{l}-0.0228 \\
(\mathbf{- 2 . 9 4})\end{array}$ \\
\hline OWN_largest & $\begin{array}{l}-0.0119 \\
(\mathbf{- 1 . 9 5 )}\end{array}$ & $\begin{array}{l}-0.0135 \\
(\mathbf{- 2 . 1 4})\end{array}$ & $\begin{array}{l}-0.0167 \\
(\mathbf{- 2 . 4 1})\end{array}$ & $\begin{array}{l}-0.0145 \\
(\mathbf{- 2 . 2 8})\end{array}$ \\
\hline SIC & $\begin{array}{l}-0.0317 \\
(-0.43)\end{array}$ & $\begin{array}{l}-0.0327 \\
(-0.45)\end{array}$ & $\begin{array}{l}-0.0169 \\
(-0.22)\end{array}$ & $\begin{array}{l}0.0074 \\
(0.10)\end{array}$ \\
\hline CFO_pressure & $\begin{array}{l}0.0250 \\
(0.26)\end{array}$ & $\begin{array}{l}0.0189 \\
(0.22)\end{array}$ & $\begin{array}{l}0.0046 \\
(0.05)\end{array}$ & $\begin{array}{l}0.0067 \\
(0.08)\end{array}$ \\
\hline \multirow[t]{2}{*}{ CFO_age } & -0.0161 & -0.0081 & -0.0075 & -0.0061 \\
\hline & $(-1.13)$ & $(-0.56)$ & $(-0.49)$ & $(-0.41)$ \\
\hline CFO_econ_edu & $\begin{array}{l}0.1084 \\
(0.42)\end{array}$ & $\begin{array}{l}0.3448 \\
(\mathbf{1 . 7 2})\end{array}$ & $\begin{array}{l}0.4910 \\
(\mathbf{2 . 1 0})\end{array}$ & $\begin{array}{l}0.4952 \\
(\mathbf{2 . 0 9})\end{array}$ \\
\hline Obs $(\mathbf{N})$ & 129 & 129 & 129 & 129 \\
\hline Wald Chi ${ }^{2}$ & 29.37 & 28.86 & 38.18 & 42.63 \\
\hline Pseudo $\mathbf{R}^{2}$ & 0.0667 & 0.0797 & 0.0952 & 0.0952 \\
\hline
\end{tabular}




\section{Table 7. Determinants of the hurdle rate}

The table reports results from robust regressions where WACC prem (the difference between a survey response WACC, and a theoretical WACC) is regressed on country and sector dummies, logarithmic sales, past one year sales growth, return on assets i.e. ROA, OWN largest (the percent of equity owned by the largest owner), SIC i.e. the number of SIC-codes for the firm at a two-digit level, CFO pressure for short-term actions (a survey response variable), CFO characteristics (CFO_age, and CFO_econ_edu), and a proxy for sophisticated capital budgeting methods, Index 4. Coefficient estimates are reported on first row for each variable, followed by z.-value in parenthesis. Significant z-values at the 10\% level are reported boldface. For variable definitions, see Appendix 2.

\begin{tabular}{|c|c|c|c|c|}
\hline Model & Model 1 & Model 2 & Model 3 & Model 4 \\
\hline DEN & $\begin{array}{l}-2.5836 \\
(\mathbf{- 1 . 7 9})\end{array}$ & $\begin{array}{l}-2.4385 \\
(-1.07)\end{array}$ & $\begin{array}{l}-3.3558 \\
(-1.49)\end{array}$ & $\begin{array}{l}-3.1545 \\
(-1.43)\end{array}$ \\
\hline FIN & $\begin{array}{l}-1.2020 \\
(-0.87)\end{array}$ & $\begin{array}{l}-0.8849 \\
(-0.39)\end{array}$ & $\begin{array}{l}-1.2448 \\
(-0.54)\end{array}$ & $\begin{array}{l}-1.9311 \\
(-0.82)\end{array}$ \\
\hline SWE & $\begin{array}{l}-3.0769 \\
(\mathbf{- 2 . 4 4 )}\end{array}$ & $\begin{array}{l}-2.9092 \\
(-1.26)\end{array}$ & $\begin{array}{l}-3.1620 \\
(-1.37)\end{array}$ & $\begin{array}{l}-3.6112 \\
(-1.52)\end{array}$ \\
\hline FIN_SEC & $\begin{array}{l}3.5443 \\
(\mathbf{2 . 0 6})\end{array}$ & $\begin{array}{l}3.8486 \\
(\mathbf{2 . 0 6})\end{array}$ & $\begin{array}{l}3.1115 \\
(1.39)\end{array}$ & $\begin{array}{l}2.6282 \\
(1.29)\end{array}$ \\
\hline IND_SEC & $\begin{array}{l}-0.5347 \\
(-0.72)\end{array}$ & $\begin{array}{l}0.0681 \\
(0.08)\end{array}$ & $\begin{array}{l}0.0526 \\
(0.06)\end{array}$ & $\begin{array}{l}0.1371 \\
(0.16)\end{array}$ \\
\hline Ln_sales & & $\begin{array}{l}-0.1760 \\
(-1.16)\end{array}$ & $\begin{array}{l}-0.1285 \\
(-0.84)\end{array}$ & $\begin{array}{l}-0.0240 \\
(-0.15)\end{array}$ \\
\hline Past Growth & & $\begin{array}{l}-0.0375 \\
(-1.43)\end{array}$ & $\begin{array}{l}-0.0353 \\
(-1.38)\end{array}$ & $\begin{array}{l}-0.0265 \\
(-1.04)\end{array}$ \\
\hline ROA & & $\begin{array}{l}-0.0063 \\
(-0.12)\end{array}$ & $\begin{array}{l}-0.0041 \\
(-0.08)\end{array}$ & $\begin{array}{l}-0.0153 \\
(-0.33)\end{array}$ \\
\hline OWN_largest & & $\begin{array}{l}0.0332 \\
(1.34)\end{array}$ & $\begin{array}{l}0.0392 \\
(1.62)\end{array}$ & $\begin{array}{l}-0.0315 \\
(1.28)\end{array}$ \\
\hline SIC & & $\begin{array}{l}-0.1173 \\
(-0.39)\end{array}$ & $\begin{array}{l}0.0211 \\
(0.07)\end{array}$ & $\begin{array}{l}-0.0391 \\
(-0.13)\end{array}$ \\
\hline CFO_pressure & & $\begin{array}{l}0.6104 \\
(1.56)\end{array}$ & $\begin{array}{l}0.5796 \\
(1.52)\end{array}$ & $\begin{array}{l}0.6401 \\
(\mathbf{1 . 6 8})\end{array}$ \\
\hline CFO_age & & & $\begin{array}{l}-0.0416 \\
(-0.70)\end{array}$ & $\begin{array}{l}-0.0483 \\
(-0.83)\end{array}$ \\
\hline CFO_econ_edu & & & $\begin{array}{l}-1.3450 \\
(-0.53)\end{array}$ & $\begin{array}{l}-1.3675 \\
(-0.55)\end{array}$ \\
\hline Index_4 & & & & $\begin{array}{l}-0.6504 \\
(\mathbf{- 2 . 2 5})\end{array}$ \\
\hline Obs (N) & 83 & 76 & 74 & 74 \\
\hline F-value & 3.63 & 2.65 & 2.79 & 2.48 \\
\hline $\mathbf{R}^{2}$ & 0.2115 & 0.2462 & 0.2491 & 0.2889 \\
\hline
\end{tabular}


Figure 1. Relative distribution of CFO responses across countries

Figure reports the relative distribution of our $157 \mathrm{CFO}$ responses across the five markets surveyed.

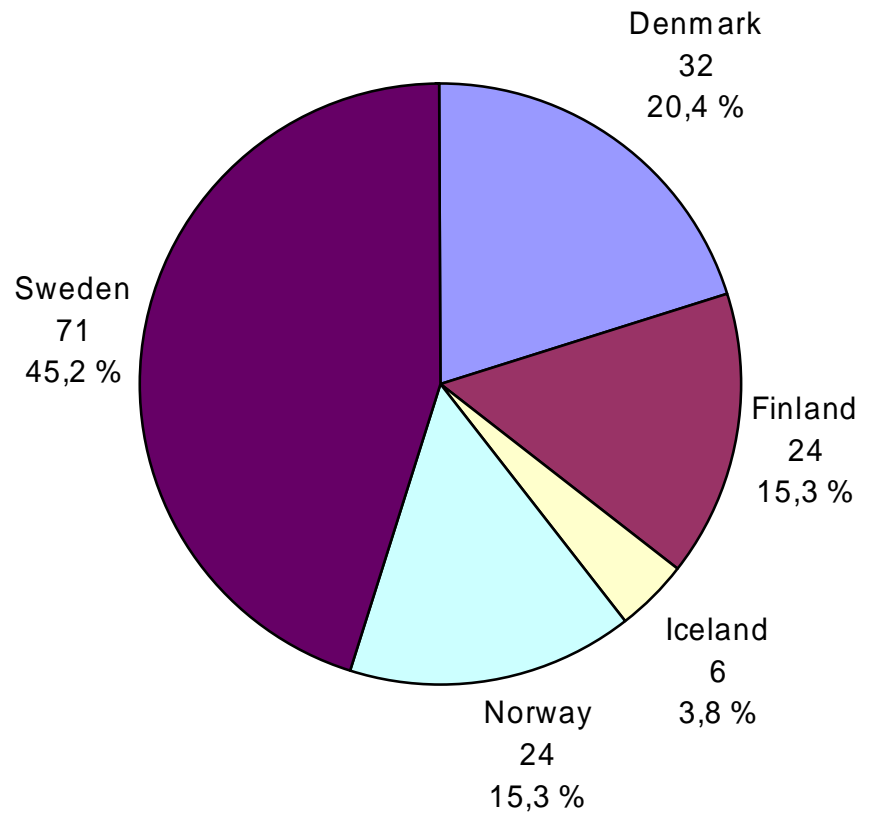


Figure 2. The distribution of estimated hurdle rate premiums

Figure reports the distribution of our 83 estimated hurdle rate premiums, i.e., of the variable WACC_prem.

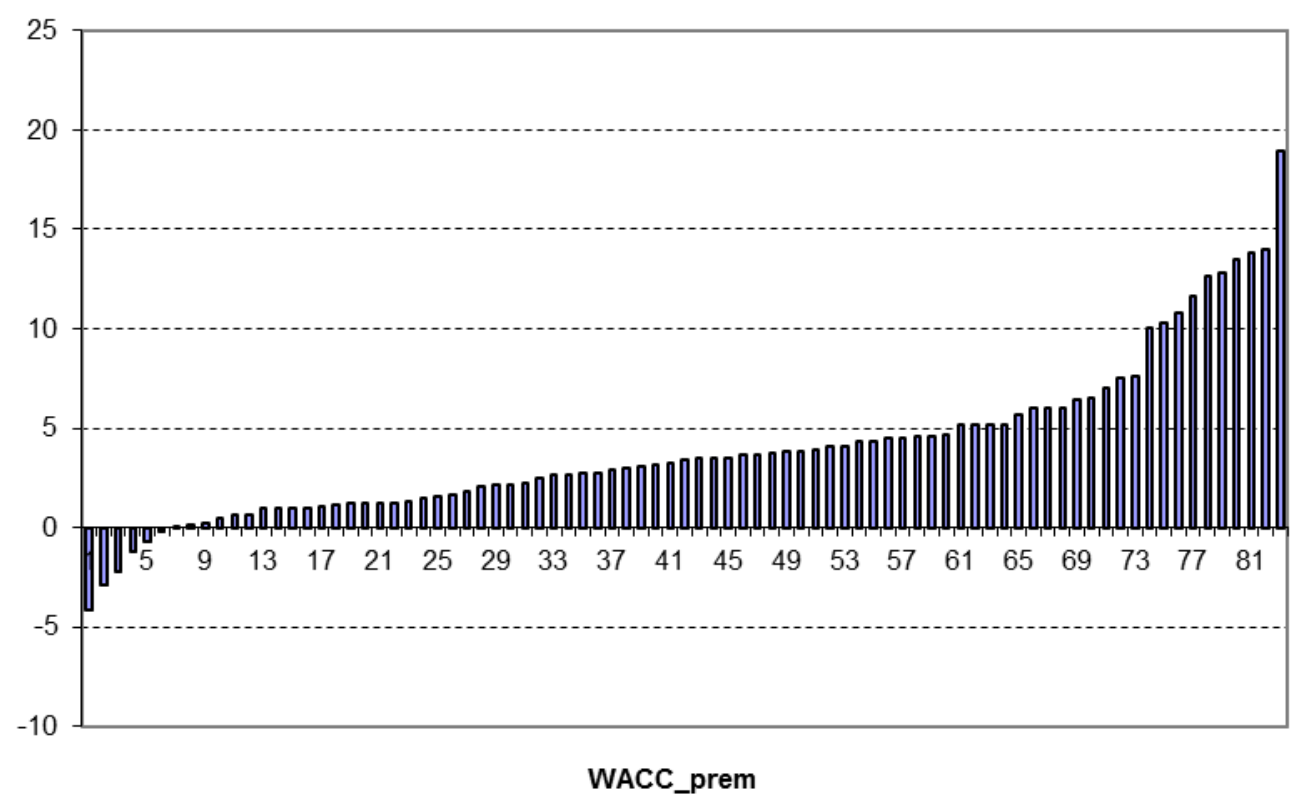

